\title{
PENERAPAN SISTEM INFORMASI PEMBELAJARAN ONLINE DI SMK AL-HUDA LAMPUNG SELATAN
}

\author{
Arif Munandar ${ }^{1}$, Heni Sulistiani ${ }^{2}$, Qadli Jafar Adrian ${ }^{3}$, Agus Irawan ${ }^{4}$ \\ Universitas Teknokrat Indonesia ${ }^{1,2,3}$ \\ STMIK Pringsewu ${ }^{4}$
}

Email : aryef.community.lampung@gmail.com ${ }^{1}$, henisulistiani@ @eknokrat.ac.id ${ }^{2}$, qadhliadrian@ teknokrat.ac.id $^{3}$, agusirawan814@gmail.com ${ }^{4}$

\begin{tabular}{lll}
\hline Received: January 15, 2020 & Accepted: February 12, 2020 & Published : March 15, 2020 \\
\hline
\end{tabular}

\begin{abstract}
The teaching and learning process needs to be done well and directed. Good quality of learning will certainly produce good learning outcomes. The learning process at SMK Al-Huda, South Lampung is still done through face-to-face. For this reason, Al-Huda Vocational School needs to develop an online learning system to facilitate teachers in sharing material, assignments and conducting examinations. And can facilitate students in obtaining material, collecting assignments and doing exam questions. The design of this system is made using the PHP programming language, MySQL database and usecase diagrams. The results of testing the system using the blackbox method involved 8 respondents and the results showed that the system built was in accordance with user requirements and could run very well.
\end{abstract}

Keywords: online, learing, system

\begin{abstract}
Abstrak
Proses belajar mengajar perlu dilakukan secara baik dan terarah. Kualitas pembelajaran yang baik, tentu akan menghasilkan hasil belajar yang baik pula. Proses belajar di SMK Al-Huda Lampung Selatan masih dilakukan melalui tatap muka secara langsung. Untuk itu, SMK Al-Huda perlu mengembangkan sistem pembelajaran online agar memudahkan guru dalam berbagi materi, tugas dan melaksanakan ujian. Serta dapat memudahkan siswa dalam memperoleh materi, mengumpulkan tugas dan mengerjakan soal ujian. Perancangan sistem ini dibuat menggunakan bahasa pemrograman PHP, database MySQL dan usecase diagram. Hasil pengujian sistem menggunakan metode blackbox melibatkan 8 responden dan hasilnya menunjukkan bahwa sistem yang dibangun telah sesuai dengan kebutuhan pengguna dan dapat berjalan dengan sangat baik.
\end{abstract}

Kata Kunci: online, pembelajaran, sistem

\section{PENDAHULUAN}

Penggunaan teknologi informasi dan komunikasi dalam proses belajar mengajar haruslah dilakukan dengan baik dan terarah agar mampu memberikan kualitas pembelajaran yang baik. Sehingga perlu adanya peningkatan bersama dalam metode pembelajaran, komunikasi dan interaksi antara siswa dan guru yang memudahkan aktifitas berbagi (sharing) sumber pembelajaran dan aktifitas diskusi tanpa terhalang oleh ruang dan waktu (Irawan, Susanti, \& Triyanto, 2015).

Pembelajaran merupakan suatu proses interaksi antara guru dan siswa. Guru merupakan faktor yang paling dominan yang menentukan kualitas pembelajaran. Kualitas pembelajaran yang baik, tentu akan menghasilkan hasil belajar yang baik pula. Salah satu tuntutan guru tersebut dapat mampu memilih metode pembelajaran yang tepat untuk mengajar. Apabila metode pembelajaran yang digunakan guru itu tepat maka pencapaian tujuan pembelajaran akan lebih mudah tercapai, sehingga nilai ketuntasan belajar siswa akan meningkat, minat dan motivasi belajar siswa juga akan meningkat dan akan tercipta Susana pembelajaran yang menyenangkan antara guru dan siswa.

Proses pembelajaran di SMK Al-Huda Lampung Selatan selama ini masih bersifat konvensional, dengan kata lain bahwa proses belajar mengajar antara guru dengan siswa hanya dilakukan dengan pertemuan langsung 
antara siswa dengan guru di dalam kelas. Jika pertemuan antara siswa dengan guru tidak terjadi atau guru yang bersangkutan tidak hadir dan waktu pembelajaran yang dibatasi pihak sekolah maka secara otomatis proses pembelajaran pun akan terhambat.

Dengan adanya sistem pembelajaran berbasis web maka dengan mudah proses belajar mengajar antara guru dengan siswa, tidak dibatasi oleh waktu dan dapat diakses kapanpun dan dimanapun selagi masih ada koneksi internet serta dapat memberikan dampak meningkatkan mutu pembelajaran dan pendidikan, sangatlah perlu bagi penyelenggara pendidikan untuk memperhatikan kebutuhan masyarakat akan pendidikan serta kemudahan segala aspek pendukungnya. E-learning yang digunakan sebagai media harus bisa dioptimalkan, sehingga penyelenggaraan pendidikan akan semakin berkembang. SMK Al-Huda Lampung Selatan merupakan satu dari banyak sekolah menengah kejuruan yang ingin memanfaatkan teknologi e-learning untuk meningkatkan pelayanan pendidikannya. Beberapa sekolah menengah kejuruan yang lain telah memanfaatkan $e$ learning.

E-learnig sebagai penggunaan teknologi informasi dan komputer untuk menciptakan pengalaman dalam belajar. E-learning biasanya menggunakan teknologi jaringan informasi dan komunikasi pada proses pembelajaran. Huruf " $e$ " pada e-learning berasal dari kata electronic, e-learning dapat diartikan semua kegiatan yang berhubungan dengan pembelajaran secara individu atau kelompok, online atau offline, dan synchronous atau asynchronous dengan menggunakan komputer ataupun peralatan elektronik lainya (Zyainuri \& Marpanaji, 2012).

Penerapan e-learning pernah dilakukan oleh SMK Respati 1 Jakarta (Nuryadi, 2018), sistem tersebut mampu membantu siswa dan guru dalam proses belajar mengajar dan mempermudah siswa untuk mengakses mata pelajaran dan juga informasi lainnya. Penelitian lainnya mengenai e-learning pernah dikembangkan oleh Fridayanthie, dkk (2018) dalam membantu proses belajar mengajar di SMK Daarut Taufiq Tangerang. Dengan adanya website e-learning SMK Daarut Taufiq ini maka siswa dapat mengakses materi yang diberikan oleh guru kapan saja. Siswa dapat mengerjakan kuis untuk mendapatkan nilai tambahan. Keterbatasan ruang dan waktu dapat diatasi dengan adanya sistem $e$-learning pada SMK Daarut Taufiq.

Setiawan, dkk (2018) juga pernah memanfaatkan media sosial untuk proses pembelajaran online di SMKN 1 Gunung Talang. Sistem elearning dibuat dengan memanfaatkan beberapa layanan web yang sudah ada dan tersedia dengan gratis yaitu : facebook, google drive dan google form. Dari hasil penelitian didapati bahwa $75 \%$ guru yang mengikuti pelatihan telah mampu membuat sebuah sistem e-learning untuk kegiatan pembelajaran. Sedangkan $25 \%$ masih kesulitan dalam membuat secara mandiri. Sulistiani, dkk (2020) juga mengusulkan sebuah media pembelajaran menggunakan konsep multimedia interaktif. Cara ini sangat efektif digunakan dalam proses pembelajaran.

Dengan berkembangnya cara pembelajaran yang dapat dilakukan secara online dan mudahnya akses pembelajaran yang tidak mengenal ruang dan waktu, maka dalam kegiatan ini penulis akan mengembangkan metode pembelajaran e-learning di SMK Al-Huda Lampung Selatan. Dengan adanya sistem ini diharapkan dapat memudahkan guru dalam berbagi materi, tugas dan melaksanakan ujian. Serta dapat memudahkan siswa dalam memperoleh materi, mengumpulkan tugas dan mengerjakan soal ujian.

\section{METODE PELAKSANAAN}

\section{Tempat dan Waktu}

Kegiatan pengembangan sistem e-learning ini akan diterapkan di SMK Al-Huda Lampung Selatan yang Terletak di Jalan Pesantren, Desa Jatimulyo, Kecamatan Jati Agung, Kabupaten Lampung Selatan. Masa kegiatan pengumpulan data dilakukan mulai dari Januari 2019 dan sistem ini diujikan pada bulan Oktober 2019.

\section{Khalayak Sasaran}

Sasaran dalam kegiatan ini yaitu guru dan siswa di SMK Al-Huda Lampung Selatan. Jumlah kelas yang ada di SMK Al-Huda yaitu sebanyak 9 kelas yang terdiri dari tiga kejuruan yaitu TKR (Teknik Kendaraan Ringan), TKJ (Teknik Komputer Dan Jaringan), TSM (Teknik Sepeda Motor) dan FARMASI.

\section{Teknik Pengumpulan Data}

Pengumpulan data dilakukan untuk memperoleh informasi yang dibutuhkan untuk mencapai tujuan. Dalam kegiatan ini, penulis menggunakan beberapa cara dalam mengumpulkan data, yaitu sebagai berikut :

1. Tinjauan Pustaka

Metode pengumpulan data atau informasi yang dilakukan dengan cara mempelajari berbagai jurnal penelitian, sumber bacaan serta buku-buku referensi yang berkaitan atau berhubungan dengan topik usulan penelitian yang sedang diteliti. 
2. Wawancara

Metode wawancara yaitu metode pengumpulan data yang dilakukan dengan cara menanyakan langsung kepada pihak yang berkaitan dengan kegiatan belajar mengajar untuk memperoleh informasi. Wawancara dalam penelitian ini dilakukan dengan ketua jurusan.

3. Observasi

Model pengamatan dilakukan dengan cara mengamati langsung proses belajar mengajar pada SMK Al-Huda Lampung Selatan.

\section{Metode Pengabdian}

Tahapan yang dilakukan dalam kegiatan pengabdian pembuatan sistem pembelajaran secara online $(e$ learning) dimulai dari memperlajari dan mengumpulkan informasi terkait permasalahan yang terjadi di SMK AlHuda dalam proses belajar mengajar. Kemudian dilanjutkan dengan mencari peluang yang ada berdasarkan permasalahan yang ada. Tahapan selanjutnya yaitu mengembangkan sebuah model dengan menggunakan salah satu metode pengembangan sistem yaitu extreme programming (Pressman, 2012). Setelah itu dilanjutkan dengan merancang sistem pembelajaran online hingga melakukan pengujian sistem ke siswa dan guru SMK Al-Huda. Tahapan penelitian yang dilakukan oleh peneliti, dapat dilihat pada gambar 1 .

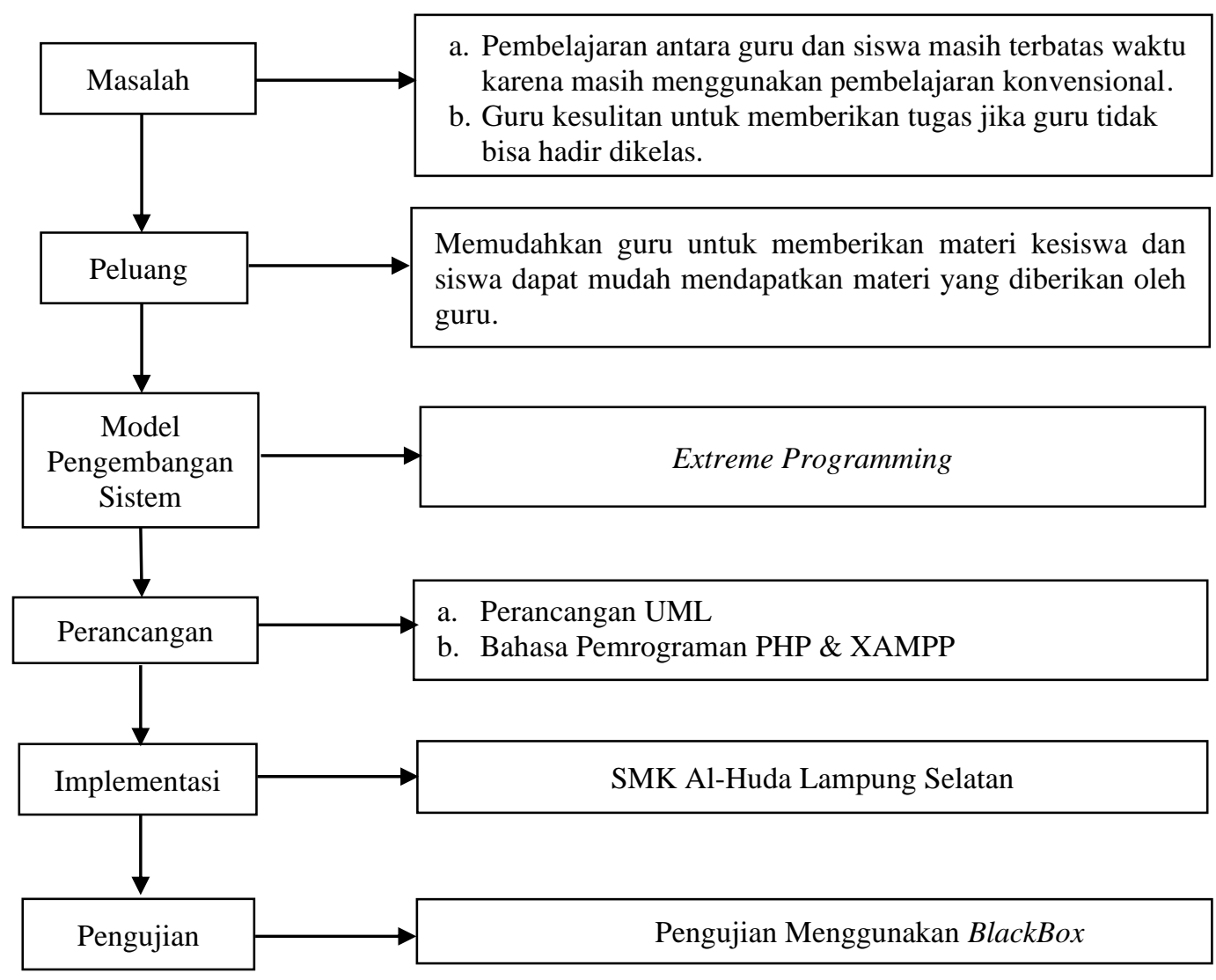

Gambar 1. Tahapan Kegiatan Pengabdian

\section{HASIL DAN PEMBAHASAN}

Hasil kegiatan pengabdian yaitu berupa perancangan sistem informasi pembelajaran online berbasis web yang memberikan kemudahan kepada admin, guru maupun siswa serta sistem ini dapat diakses kapanpun dan dimanapun. Perancangan sistem informasi pembelajaran online berbasis web yang diimplementasikan menggunakan bahasa pemrograman PHP yang merupakan bahasa pemrograman multi platform, PHP dapat dijalankan di semua komputer jika ada software XAMPP. PHP (Personal Home Page) adalah bahasa pemrograman yang digunakan secara luas untuk penanganan pembuatan dan pengembangan sebuah web dan 
Journal of Social and Technology for Community Service (JSTCS), Vol: 01, No: 01, 7-14

bisa digunakan pada HTML (Husni, 2014). Sistem ini menggunakan Database MySQL yang dapat dijalankan pada berbagai jenis komputer sehingga penerapan sistem tidak terbatas pada spesifikasi perangkat tertentu.

Gambaran sistem dibangun dengan menggunakan use case diagram. Menurut Rosa dan Shalahuddin (2018), Use case diagram atau diagram use case merupakan pemodelan untuk kelakuan (behavior) sistem informasi yang akan dibuat. Use case mendeskripsikan sebuah interaksi antara satu atau lebih aktor dengan sistem informasi yang akan dibuat. Secara kasar, use case digunakan untuk mengetahui fungsi apa saja yang ada didalam sebuah sistem informasi dan siapa saja yang berhak menggunakan fungsi-fungsi itu. Use case diagram dari sistem pembelajaran online ini dapat dilihat pada gambar 2.

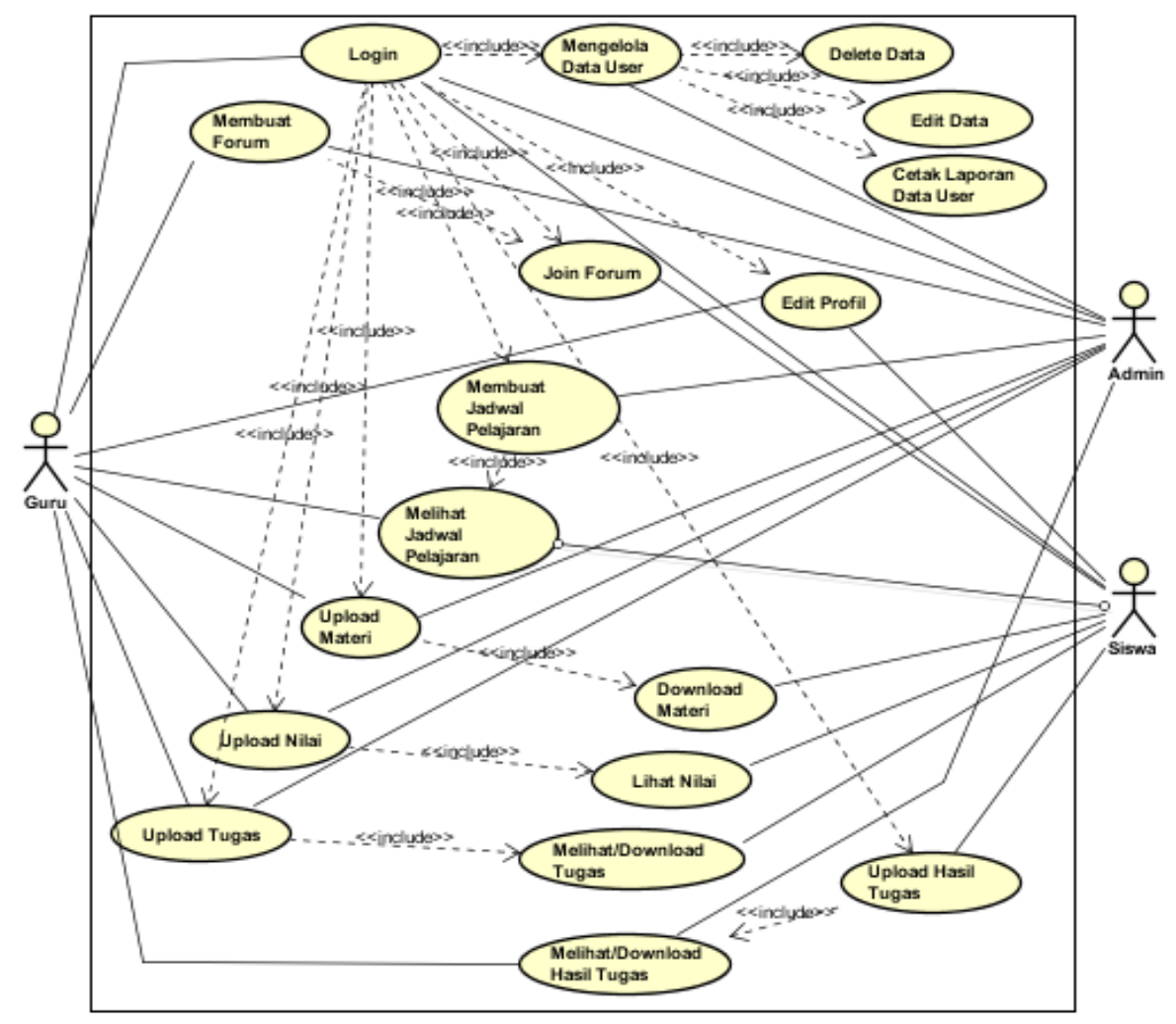

Gambar 2. Use Case Diagram Sistem Pembelajaran Online (E-Learning) SMK Al-Huda dilakukan

Berikut ini dijelaskan mengenai hasil dari pengembangan sistem pembelajaran online yang telah

1. Tampilan Dashboard Admin

Pada halaman dashboard admin terdapat menu master yang berisikan menu master admin, tahun ajaran, jurusan, kelas, guru, siswa, pelajaran, jadwal pelajaran dan juga terdapat menu manajemen yang berisikan materi, tugas, nilai dan terdapat menu laporan kelas, guru, siswa, terdapat juga menu jadwal pelajaran, forum diskusi, profil dan logout. Tampilan dashboard admin dapat dilihat pada gambar 3.

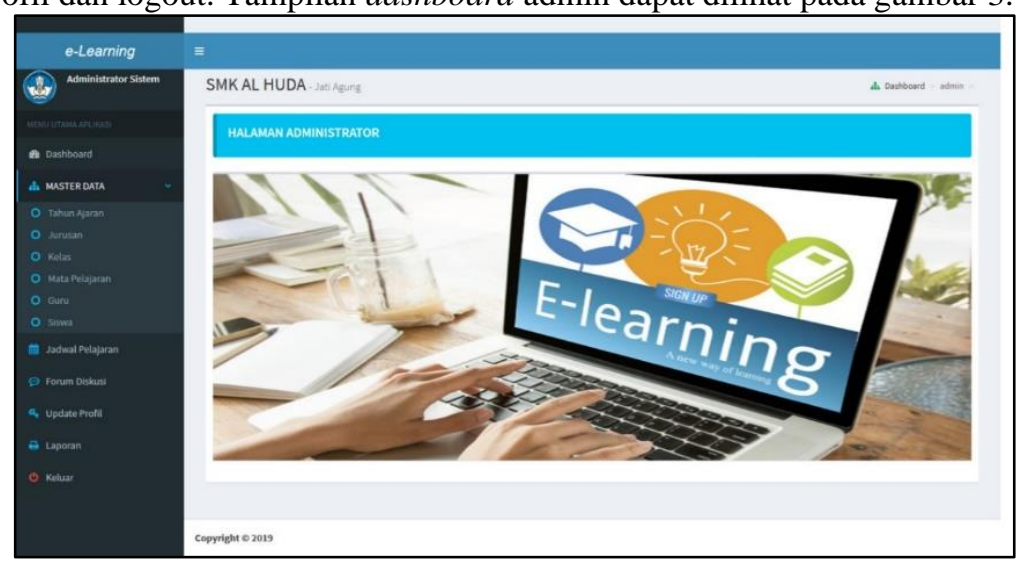

Gambar 3. Halaman Dashboard Admin 
2. Tampilan Dashboard Guru

Pada halaman dashboard guru terdapat menu-menu yang berisikan menu profil guru, jadwal mengajar guru, upload materi, upload tugas dan forum diskusi, input nilai, download hasil tugas, keluar dan terdapat foto guru yang telah login. Tampilan dashboard guru dapat dilihat pada gambar 4.

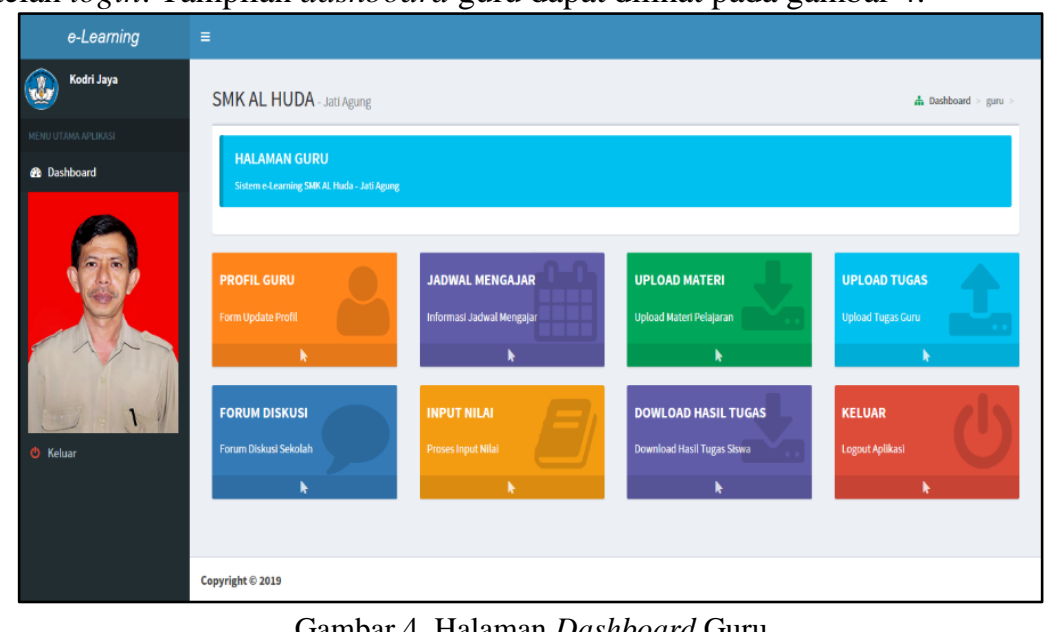

Gambar 4. Halaman Dashboard Guru

3. Tampilan Halaman Jadwal Mengajar Guru

Pada halaman manajemen jadwal mengajar guru terdapat informasi data jadwal mengajar yang mana dapat mempermudah guru untuk mengetahui jadwal guru mengajar. Tampilan halaman jadwal mengajar dapat dilihat pada gambar 5 .

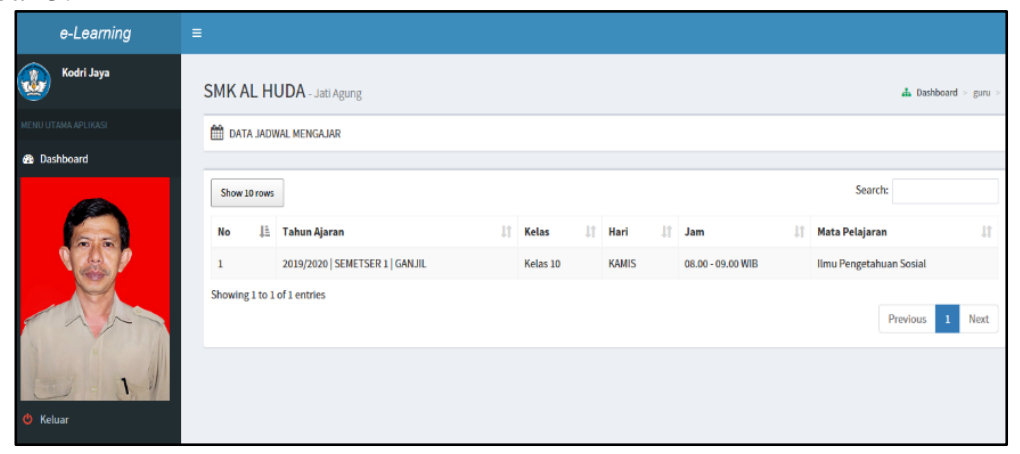

Gambar 5. Halaman Jadwal Mengajar Guru

4. Tampilan Halaman Unggah Materi

Pada halaman data materi tersebut terdapat tombol tambah untuk menambahkan data manajemen materi, tombol edit untuk mengedit data materi, tombol hapus untuk menghapus data materi dan tombol cari untuk mencari data manjemen materi yang di inginkan berdasarkan kode data manajemen materi dan tombol download yang mana guru bisa mendownload materi. Tampilan halaman data materi dapat dilihat pada gambar 6 .

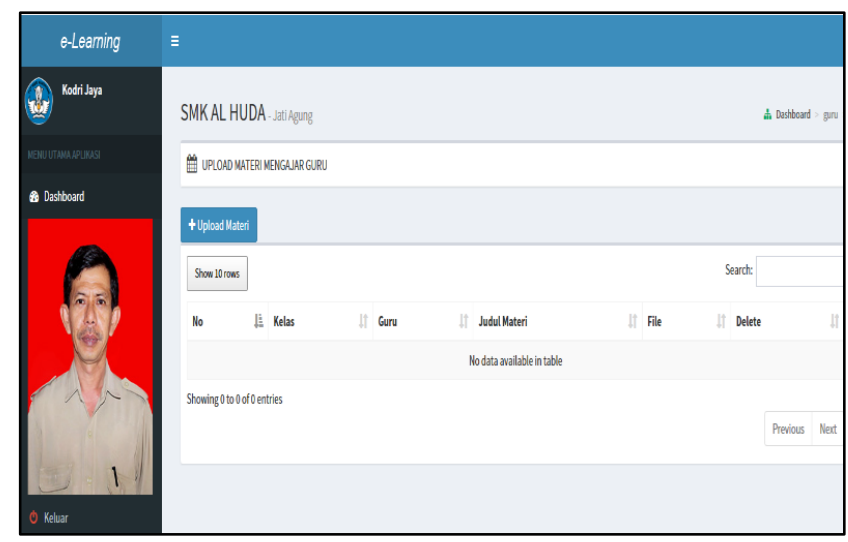

Gambar 6. Halaman Unggah Materi 
5. Tampilan Halaman Tugas dan Ujian

Dalam form tugas dan ujian terdaat dua fungsi yaitu untuk tugas dan ujian, jika admin ingin memberi tugas maka admin input judul sebagai tugas dan jika admin ingin memberi ujian atau ulangan maka dalam judul sebagai ujian. Pada halaman data tugas dan ujian tersebut terdapat, tombol tambah untuk menambahkan data tugas dan ujian, tombol hapus untuk menghapus data tugas dan ujian, tombol data jawaban untuk melihat data jawaban tugas dan ujian dari siswa dan tombol cari untuk mencari data tugas dan ujian yang di inginkan berdasarkan kode data tugas dan ujian. Tampilan halaman data tugas admin dapat dilihat pada gambar 7.

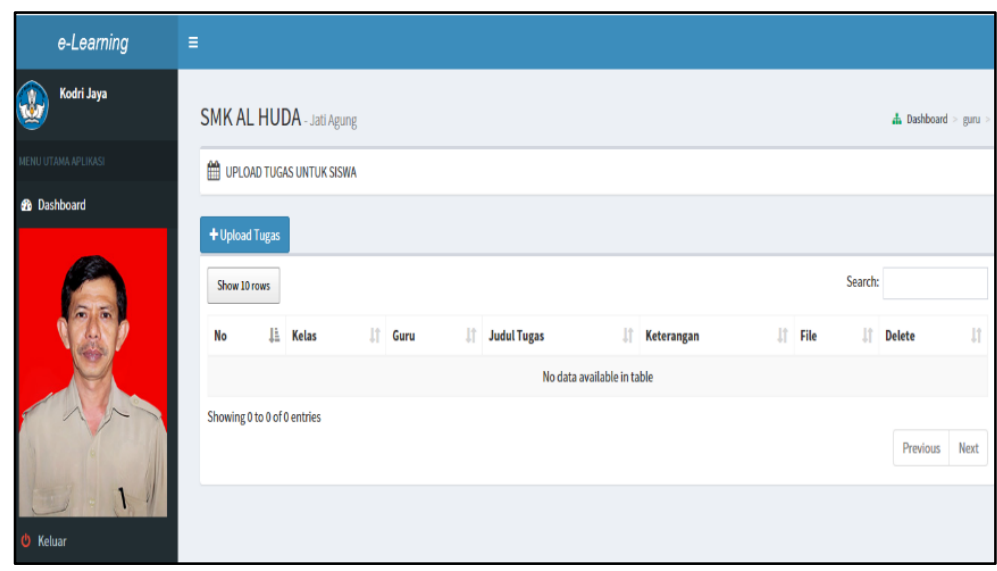

Gambar 7. Halaman Tugas dan Ujian

6. Tampilan Halaman Forum Diskusi

Pada halama ini, guru bisa membuat tema diskusi yang ingin di bahas di forum jika sudah selesai pembahasanya maka pembuat forum itu yang bisa menghapus, didalam forum ini akan terlihat di user guru, admin dan siswa jadi semua user bisa berpartisipasi dalam pembahasan yang telah dibuat. Tampilan halaman forum diskusi guru dapat dilihat pada gambar 8 .

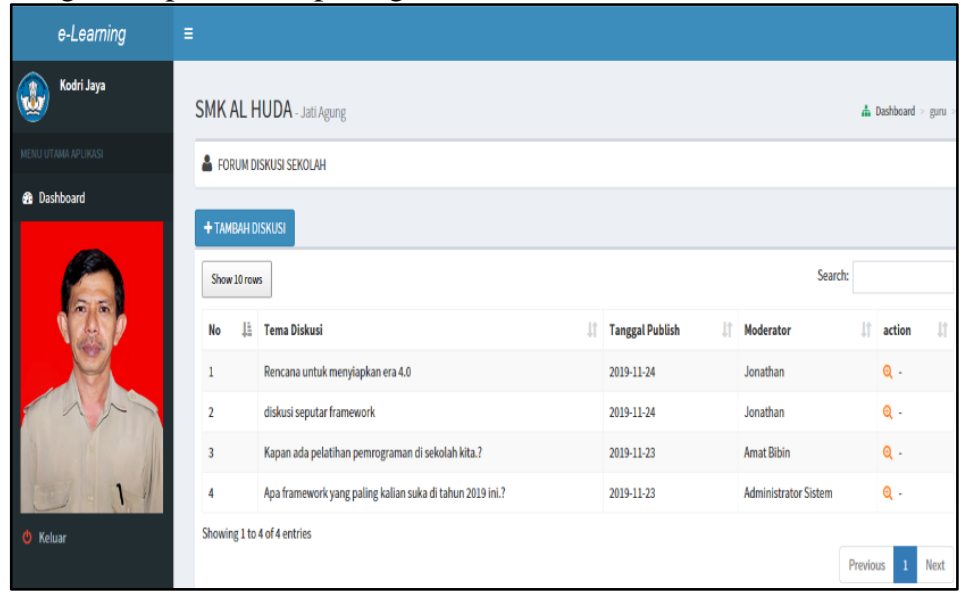

Gambar 8. Halaman Forum Diskusi

7. Tampilan Halaman Input Nilai

Halaman nilai ini berfungsi untuk guru menginputkan nilai, tombol tampilkan berfungsi untuk menampilkan keseluruhan nilai yang sudah diinputkan oleh guru setelah diinputkan nilai maka sistem akan mengeluarkan hasil yaitu berupa huruf mutu yang nantinya akan tampil di user siswa. Tampilan halaman input nilai dapat dilihat pada gambar 9 . 


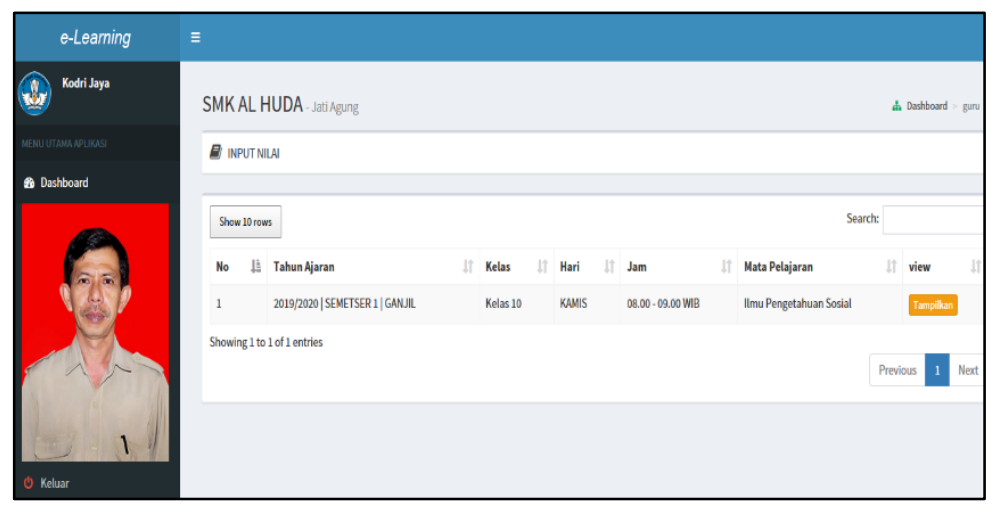

Gambar 9. Halaman Input Nilai

8. Halaman Dashboard Siswa

Pada halaman dashboard siswa terdapat menu-menu yang berisikan menu profil siswa, jadwal pelajaran, download materi, upload tugas dan ujian, forum diskusi, lihat nilai, upload hasil tugas, keluar dan terdapat foto siswa yang telah login. Tampilan dashboard siswa dapat dilihat pada gambar 10.

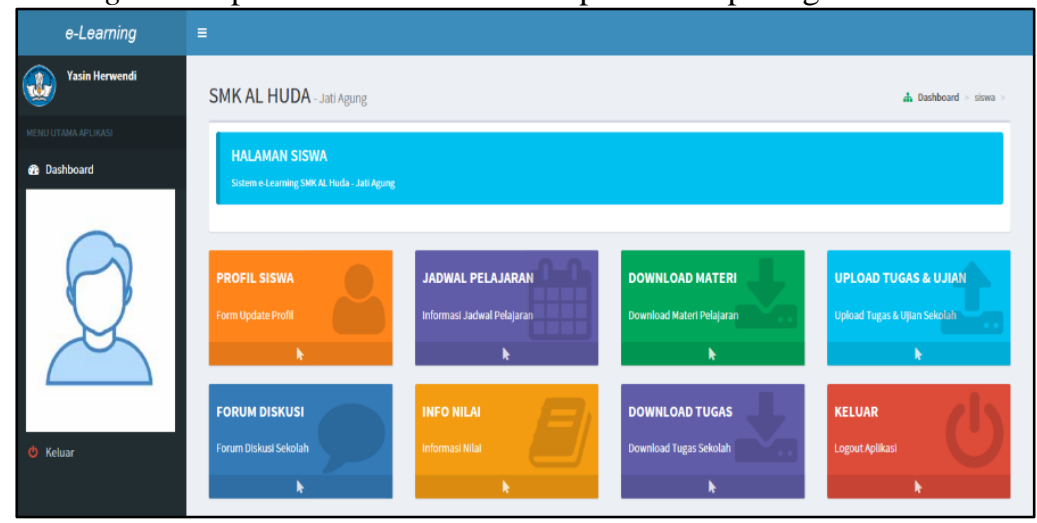

Gambar 10. Halaman Dashboard Siswa

Setelah sistem ini dibangun, tahapan selanjutnya yaitu melakukan pengujian sistem guna mengetahui apakah sistem ini sesuai dengan kebutuhan pengguna. Pada penelitian ini pengujian menggunakan blackbox yang dilakukan oleh guru dan siswa SMK Al-Huda Lampung Selatan. Pengujian black-box memungkinkan perekayasa perangkat lunak mendapatkan serangkaian kondisi input yang sepenuhnya menggunakan semua persyaratan fungsional untuk suatu program (Dondeti, 2012). Pengujian sistem ini melibatkan 8 responden dalam mengujicoba penggunaan sistem. Hasil pengujian menunjukkan bahwa sistem yang dibangun telah sesuai dengan kebutuhan pengguna dan dapat berjalan dengan sangat baik.

\section{KESIMPULAN}

Berdasarkan hasil pengembangan sistem pembelajaran online (e-learning) di SMK Al-Huda Lampung Selatan, dapat disimpulkan bahwa perancangan sistem ini dibuat menggunakan bahasa pemrograman PHP, database MySQL dan dirancang dengan pemrograman berorientasi objek yaitu usecase diagram. Hasil pengujian sistem menggunakan metode blackbox yang telah dilakukan dengan melibatkan 8 responden yang menunjukkan bahwa sistem yang dibangun telah sesuai dengan kebutuhan pengguna dan dapat berjalan dengan sangat baik.

\section{UCAPAN TERIMA KASIH}

Penulis mengucapkan terima kasih yang sebesar-besarnya kepada Kepala Sekolah SMK Al-Huda yang telah memberikan izin dalam proses pengembangan sistem ini. Tidak lupa ucapan terima kasih juga kepada Kepala Jurusan, Guru dan Siswa yang telah memberikan banyak informasi dalam proses pengumpulan data.

\section{REFERENSI}

Dondeti. 2012. Black Box And White Box Testing Techniques- A Literature Review. Internasional Journal Of Embedded System an Applications (IJESA) Vol.2. no.2

Fridayanthie, E.W., Aziz, M.A., Kusumaningrum, A. 2018. Rancang Bangun (Sistem Informasi E-learning Berbasis Web 
Pada Daarut Taufiq Tangerang, Jurnal Swabumi, Vol.6 No.2.

Husni. 2014. Pemograman Web dengan HTML. Bandung: Informatika.

Irawan, Y., Susanti, N., \& Triyanto, W. A. 2015. Analisa dan Perancangan Sistem pembelajaran Online. Jurnal Simentris, 346.

Nuryadi, N. 2018. Rancang Bangun Aplikasi Website e-learning Pada SMK Respati Jakarta, Jurnal Teknik Komputer, Vol.4 No 1.

Presman, R., S. 2012. Rekayasa Perangkat Lunak, Edisi 7. Diterjemahkan oleh : Nugroho, A. Yogyakarta : ANDI.

Rosa, AS, Shalahuddin. M. 2018. Rekayasa Perangkat Lunak. Bandung : Informatika.

Setiawan, D., Lestari, S., Putra, D.S., azmi, M. 2018. Pemanfaatan Media Sosial Untuk Membangun Sistem E-learning di SMKN 1 Gunung Talang, Jurnal Inovasi Vokasional dan Teknilogi, Vol. 18 No. 1.

Sulistiani, Heni, Dedi Darwis, Dwi Shinta M Silaen, dan Diana Marlyna. 2020. Pengembangan Media Pembelajaran Akuntansi Berbasis Multimedia (Studi Kasus: SMA Bina Mulya Gading Rejo, Pringsewu).

Zyainuri, \& Marpanaji, E. 2012. Penerapan E-learning Moodle. Pendidikan Vokasi, 411. 